\title{
The Prosecution of Rape in Wartime: Evidence from the Mau Mau Rebellion, Kenya 1952-60
}

\section{DAVID M. ANDERSON AND JULIANNE WEIS}

In July 2012, a landmark hearing before the High Court in London found that the British government had a case to answer concerning human rights abuses, including torture and rapes, allegedly perpetrated by British colonialists in Kenya, during the Mau Mau counterinsurgency of the 1950s. ${ }^{1}$ Among the four elderly Kenyan claimants in court that day was a Kikuyu woman, Jane Mara, whose testimony related the sexual abuses she had suffered. Jane had been only 15 years of age, in 1954, when she was accused of being a Mau Mau sympathizer, and along with other villagers, she was taken for interrogation. The experience Jane Mara recounted was horrific. Beaten repeatedly by her inquisitors, she was then pinned to the floor by four African guards who held her thighs apart, while another guard forced a glass bottle into her vagina, using the sole of his boot to direct the bottle deeply into her. The pain was excruciating, and Jane realized that the bottle had been heated. When this ordeal came to an end, she

1. Judgment, Mr Justice McCombe, High Court of Justice (Queens Bench), Case HQ09X02666, Ndiku Mutua et al v The Foreign \& Commonwealth Office, October 5, 2012.

David M. Anderson is a Professor of African History at the University of Warwick, and a Research Associate in History at Stellenbosch University <d.m.anderson@ warwick.ac.uk>. Julianne Weis holds a doctorate from the Wellcome Unit for the History of Medicine, University of Oxford <juliannerose@gmail.com>. The authors thank Aidan Russell, Patrycja Stys, and Anna Shoemaker for assistance with data collection, and Dan Leader, Zoe Marks, Brett Shadle, Huw Bennett, and Jocelyn Alexander for comments and advice. 
was compelled to sit and watch as the three other young women were subjected to the same torture. ${ }^{2}$

This was the first time that such a story of sexual crimes in the counterinsurgency against the Mau Mau rebels had been laid before a British court; however, for Kenyans, the detail of these claims was all too familiar. In 1998, the publication of political activist Wambui Waiyaki Otieno's memoirs had caused a stir with her revelation of her brutal multiple rape at the hands of a British police officer in a detention camp in 1960. A prominent public figure in Kenya, Otieno's candor was all the more remarkable for the fact that the rape had resulted in pregnancy and the birth of her daughter. ${ }^{3}$ Otieno's experience echoed earlier accounts from the 1950s. In his biographical account of the rebellion, Mau Mau forest fighter Karari Njama poignantly recalled his return to his home in Nyeri after the war only to find that his wife had been raped by a member of the local African militia (the Kikuyu Home Guard), and had borne an illegitimate child. ${ }^{4}$ This trope was even taken up by the distinguished Kenya fiction writer Ngugi wa Thiong'o, whose rebel hero in A Grain of Wheat, Gikonyo, returns home in similar circumstances. ${ }^{5}$ More recently, from 2002 onwards, the collection by the Kenya Human Rights Commission of testimony on colonial abuses brought to light a growing catalogue of rape accusations, similar accounts being highlighted in Caroline Elkins's monograph on the story of the British detention camps in Kenya, published in 2005. Elkins quotes from the oral testimonies of several Kikuyu women who related their experience of rapes and other sexual assaults while in the custody of security personnel, including events very similar to those described by Jane Mara. ${ }^{6}$

This article presents the first documentary evidence from Kenya in the 1950 s that corroborates and enlarges upon these legal and oral testimonies and memoirs. Accusations of rapes and sexual assaults by state security

2. Summarized from David M. Anderson, "Mau Mau in the High Court and the 'Lost' British Empire Archives: Colonial Conspiracy or Bureaucratic Bungle?" Journal of Imperial \& Commonwealth History 39 (2011), 699-716. Jane Mara's ordeal was widely reported in the media; therefore, we have used her name here. For all other cases we have preserved the anonymity of the victim.

3. Wambui Waiyaki Otieno, Mau Mau's Daughter: A Life History (Boulder: Lynne Rienner Publishers, 1998), 81-90.

4. Karari Njama and Donald L. Barnett, Mau Mau from Within (London: MacGibbon \& Kee Ltd, 1966), 128.

5. Ngugi wa Thiong'o, A Grain of Wheat (London: Heinemann, 1972), 132.

6. Caroline Elkins, Britain's Gulag: The Brutal End of Empire in Kenya (London: Jonathan Cape, 2005), 220-21, and 226-27 for sexual torture within detention camps and prisons; 244-45, 257, and 269-71 for rape by Kikuyu Home Guard; and 247-48, 252, 254, and 256-57 for rape by other arms of the security services, including the British Army. 
personnel are littered through the substantial body of new archival material that has been released as a consequence of the Mau Mau compensation case mounted in the High Court in London. Known collectively as the "Hanslope Disclosure," and covering thirty-six other former British colonies as well as Kenya, ${ }^{7}$ this body of material (nearly 23,000 files in all) includes approximately 700 files dealing with the administration of the Kenyan rebellion. A significant number of these files relate specifically to the investigation and prosecution of allegations against the security forces between 1953 and 1959, including cases of rape and sexual crimes. ${ }^{8}$

This documentary evidence is powerful and important precisely because it relates to specific cases in which investigations - and sometimes prosecutions - were initiated by the state at the time. The existence of these cases may at first appear surprising. Legal attitudes to rape in colonial Kenya in the 1950s were generally unsympathetic to prosecution, as they were also in Britain at this time. ${ }^{9}$ While examining these papers for the information they can give us on the character and extent of sexual crimes, we must also ask how it was that such cases were brought to the attention of legal officers at all? These assaults were committed upon civilian Kikuyu women by African and British agents of the colonial state; therefore, the decision to prosecute related to the discipline and control of the security forces. As we will discuss, the colonial state sought to escape court hearings wherever possible by denying or deflecting evidence, generally preferring to avoid legal remedies. For the colonial authorities, rape was a "difficult" charge. Among victims, too, this new archival evidence suggests reluctance on the part of Africans to seek formal prosecution, this being reinforced by the circumstances of the conflict in which the

7. Mandy Banton, "Destroy? 'Migrate'? Conceal? British Strategies for the Disposal of Sensitive Records of Colonial Administrations at Independence," Journal of Imperial \& Commonwealth History 40 (2012), 321-35; and Edward Hampshire, "'Apply the Flame More Searingly.' The Destruction and Migration of the Archives of the British Colonial Administration: A South East Asia Case Study," Journal of Imperial \& Commonwealth History 41 (2013), 334-52.

8. These files from the Hanslope Disclosure have now been transferred to The National Archive (hereafter TNA), Kew, and have been released under the category "Migrated Archives," designated as TNA FCO 141. At no point in these records is a definition of rape offered. All the cases report female victims. The vast majority of cases relate accusations of forced vaginal penetration, with a small number describing the forced insertion of objects into the vagina. In a few cases, the evidence presented does not indicate the precise nature of the assault.

9. Joanna Bourke, Rape: A History from 1860 to the Present (London: Virago Press, 2007); and Nesta H. Wells, "Sexual Offences as Seen by a Woman Police Surgeon," British Medical Journal, December 6, 1958, 1404-8, for patterns of offending and prosecution in Manchester between 1927 and 1954. 
victims were usually stigmatized as supporters of the rebels, whereas the perpetrators were servants of the government. The evidence on these cases thus provides a unique insight as to the way that rape was treated in a colonial context during the 1950s, and adds to the small but growing body of literature that addresses the question of how sexual crimes are (or are not) prosecuted in wartime. Rape in 1950s Kenya was a widespread and potent element of the counterinsurgency.

The main part of this article presents the new body of documentary evidence on rape in 1950s Kenya, giving the background to the Mau Mau rebellion and the British counterinsurgency and discussing specific cases for which investigations were initiated. To analyze the cases, we will look primarily at investigations against three branches of the colonial security services: the military, the African Home Guard, and the police. The concluding part of the article then discusses the wider historical literature on rape in wartime, to illustrate that few historical cases before 1990 have been examined in any depth, and to identify what might be distinctive and valuable about the Kenyan experience.

\section{New Evidence on Rape in Wartime Kenya}

The counterinsurgency mounted against Kenya's Mau Mau rebels was the most savagely fought of Britain's wars of decolonization after 1945.10 Between October 1952 and the ending of the state of emergency, in January 1960, unofficial estimates suggest that rebel casualties were between 20,000 and $30,000 .{ }^{11}$ At the peak of the war, in 1955, more than 70,000 Africans were held in British prisons and detention camps, the vast majority being incarcerated without charges having been brought against them. The rebellion was concentrated amongst the 1,000,000 Kikuyu speakers of Kenya's Central Province and Mount Kenya region. The British counterinsurgency was a "dirty war," in which the civilian Kikuyu population, identified as the "passive wing" of the rebellion, was subjected to oppressive scrutiny by the colonial state. Draconian laws gave the police and other security services wide discretionary powers to

10. David M. Anderson, Histories of the Hanged: Britain's Dirty War in Kenya and the End of Empire (New York: WW Norton, 2005); and Huw Bennett, Fighting the Mau Mau: The British Army and Counter-insurgency in the Kenya Emergency (Cambridge: Cambridge University Press, 2012).

11. John Blacker, "The Demography of Mau Mau: Fertility and Mortality in Kenya in the 1950s — a Demographers View," African Affairs 106 (2007), 205-27. The official figures are to be found at Colony \& Protectorate of Kenya, The Origins and Growth of Mau Mau: An Historical Survey (Corfield Report) (Nairobi: Government Printer, 1960), appendix H. 
detain and interrogate suspects, a process known in Kenya by the euphemism of "screening." This led to reports of random and widespread violence against civilians, including sexual assaults, from the very earliest months of the conflict. ${ }^{12}$

British Army regiments were deployed to Kenya from the beginning of the emergency, operating alongside the King's African Rifles, a regiment with African rank-and-file and British officers. These military units were primarily responsible for chasing down the rebel bands in the forests and mountains, but they also acted in aid of the civil authorities in the settled areas of Central Province and elsewhere. ${ }^{13}$ A third military formation, the Kenya Regiment, made up of approximately 300 recruits from the European white settler community, played a prominent role in intelligence gathering and in the command of African auxiliary forces that were primarily engaged in civil security. ${ }^{14}$ Law and order among the civilian population was the domain of the Kenya Police, heavily augmented by several auxiliary forces, most notably the Kenya Police Reserve, greatly expanded during the emergency to 2000 full-time officers and 4800 part timers, and the Tribal Police, recruited and controlled by African chiefs and headmen and operating mainly in the rural areas. ${ }^{15}$ Finally, Kikuyu "loyal" to the government were, in the early months of 1953 , formed into a militia known as the Home Guard, colloquially referred to as "Loyalists." This militia grew to a force of 25,600 by March 1954, more than matching the rebel armies. ${ }^{16}$ British strategy pushed the Home Guard into the forefront of the counterinsurgency, pitting Kikuyu rebel against Kikuyu "Loyalist." Home Guard also prosecuted the war against the "passive wing" of Mau Mau among the wider civilian population, punishing the rebels and their supporters alike. ${ }^{17}$

The substantial body of new archival material, the Hanslope Disclosure, contains many detailed and previously unknown allegations of rapes and sexual assaults made against the British security services in Kenya. In

12. David M. Anderson, "British Abuse and Torture in Kenya's Counter-Insurgency, 1952-1960," Small Wars \& Insurgencies 23 (2012), 700-719.

13. Bennett, Fighting the Mau Mau, 8-29; and Huw Bennett, "Soldiers in the Court Room: The British Army's Part in the Kenya Emergency Under the Legal Spotlight," Journal of Imperial \& Commonwealth History 39 (2011), 717-30.

14. Anderson, Histories of the Hanged, 85

15. Anthony Clayton, Counter-insurgency in Kenya, 1952-60 (Nairobi: Transafrica Publishers, 1976), 3-13, 42-52; and Anderson, Histories of the Hanged, 85.

16. Figures collated from Kenya National Archive, Nairobi (hereafter KNA), MAA/7/761.

17. Daniel Branch, Defeating Mau Mau, Creating Kenya: Counter-insurgency, Civil War, and Decolonization (Cambridge: Cambridge University Press, 2009), and Daniel Branch, "The Enemy Within: Loyalists and the War Against Mau Mau in Kenya," Journal of African History 48 (2007), 291-316. 
May 1953, for example, complaints were made regarding the "many abuses of the Home Guard," including rapes of women, while conducting screening in the Londiani Division of the Rift Valley Province. The official response acknowledged that abuses had taken place, but failed to address the specific allegation of rapes. At the same time, the complainant - a preacher with the local Moral Rearmament Movement in the district-was privately informed that among the Africans who had told him about these events were some who were suspected of Mau Mau activities. This was to become a familiar pattern, with accusations of rape being dismissed and represented as malicious efforts to undermine African staff within the colonial administration. The Londiani complaint was among a larger body of similar allegations that resulted in an internal investigation into the conduct of the Home Guard in the screening camps, and the issuing of instructions to keep tighter control over screening teams, but rapes were not formally investigated. ${ }^{18}$

In another report, from January 1955, two women were assaulted in the Home Guard camp at Makadara, in Nairobi, objects being inserted into their vaginas in an act of torture and humiliation. These assaults were perpetrated by a group of Kikuyu women, then living with Home Guard at the camp. Investigators described the assailants as "prostitutes," who had "thrown their lot in with the government." Information supplied by these women had been used in security operations, and this accounted for their presence under the "protection" of the Home Guard. This case came to court, with the assailants being convicted by the local magistrate. Evidence produced at this hearing showed that Chief Kioko, Commander of the Home Guard at Madakara, was well aware of the sexual abuse of female Mau Mau suspects, and that this was a common practice at Makadara. After this incident, Chief Kioko was transferred from Makadara to rural Meru, and given the rank of Sergeant Major in a new Home Guard unit. ${ }^{19}$

A third example comes from early 1956, when two women alleged that they had been raped at a labor camp in Machakos District, by the African headman in command of the camp. Initial investigations revealed that other Home Guard and Tribal Police had also raped young girls at the camp. However, despite acknowledging "that the headman took full advantage of the sexual opportunities that his position and the detention of a number of girls presented him with," colonial officials elected not to prosecute because of difficulties establishing the "question of consent." 20 The

18. TNA FCO 141/6750, correspondence between May 1953 and September 1954.

19. TNA FCO 141/6209, Antony C. Small (District Commissioner, Nairobi) to officer in charge, Nairobi Extra-Provincial District, January 27, 1955, and related correspondence.

20. TNA FCO 141/6205, "Kenya: Mau Mau Unrest-Allegations at Ndithi Women's Camp." 
accused men either claimed that the women had consented, or they simply denied the assaults. With contradictory accounts, a lack of medical evidence, and no other witnesses willing to give evidence, the prospects for conviction were slim.

These examples are typical of many references to such cases in the Hanslope Disclosure that begin to illustrate the range of issues raised by rape allegations, but a more coherent picture can be obtained from closer examination of the cases that were formally reported to the Chief Secretary's Complaints Co-ordinating Committee (CSCCC). The papers of this Committee are among the most important sources revealed in the Hanslope Disclosure. It was initially set up in mid-January 1954, as a "watch committee" to "receive complaints of ill-treatment by members of the Security Forces and to direct such complaints to the appropriate authorities." ${ }^{21}$ The minutes of the first seven meetings are missing from the record, but from April 26, 1954 until the disbandment of the committee in November 1959, there is a full record of the cases reported. ${ }^{22}$ The deputy public prosecutor and under-secretary of defence both attended the CSCCC. The minutes were widely circulated, copies going to all senior officials in Nairobi, including the governor and other members of the War Council, senior legal officials, and ministers. Copies of the minutes also came back to London for the attention of the secretary of state for the Colonies.

Important though the records of the CSCCC are, they by no means represent a complete account of all accusations made against the security forces: only those that had first been formally notified to the Criminal Investigations Department (C.I.D.) then came to the CSCCC. In many instances, rape allegations were not the reason for the initial C.I.D. investigations, but only emerged as inquiries drew together a more complete picture of the circumstances of the event. This tends to suggest that charges of rape were only rarely brought directly to the C.I.D. Moreover, although allegations of abuses from within the detention camps emerged at the time in letters written by detainees and sent to activists in Kenya and in Britain who then sought to publicize these events, only one such complaint - that of the sexual abuse of a detainee at the women's reception

21. TNA FCO 141/6567, Lt Col Bevan to Cabinet Office, London, December 17, 1954.

22. The committee met biweekly until January 1955, then monthly until March 1958, and then irregularly until November 1959. The papers are in TNA FCO 141/6567, "Kenya: Mau Mau unrest - Complaints Co-ordinating Committee, 1954-55" and TNA FCO 141/6568, "Kenya: Mau Mau Unrest - Complaints Co-ordinating Committee, 1955-59." For a shorter run of papers, see TNA CO 822/1253, "Complaints Co-ordinating Committee in Kenya 1957-59." See also Bennett, Fighting the Mau Mau, 123-24. 
camp at Kirigiti-found its way to the CSCCC. ${ }^{23}$ This was because there was no formal bureaucratic requirement to report such complaints from within the detention camps to any specified authority, in contrast with unexplained deaths in the camps, which required notification to the police. The experience of women detainees, therefore, requires a separate study, necessarily drawing upon a different set of sources.

The CSCCC papers now available record fifty-six separate sexual crimes, spanning 1954 to 1959 , for which details are provided. ${ }^{24}$ All were perpetrated by employees of the colonial administration or members of the security forces: twenty-three cases involved members of the Kenya Police, another three cases relating to the Kenya Police Reserve and three to officers of the Prison Service; Tribal Police were accused in six cases, and the Home Guard was accused in ten cases. In another case, the accused was a screening officer, and in the final case, the affiliation of the accused was not recorded. Military units, the British Army, the King's African Rifles, and the Kenya Regiment featured in nine of the cases. The incidence of reported cases shows a decline toward the end of the period, with all but three cases occurring between 1954 and 1957. In terms of outcomes, we know that from the fifty-six investigations only twenty-nine cases were prosecuted, and that in twenty-four cases it was decided that there was insufficient evidence to merit prosecution. In three cases, the records are incomplete and we do not know the outcome. Although prosecution rates varied considerably across the services, it is striking that all cases involving Home Guard reported to the CSCCC came to court and that these cases also had the highest likelihood of conviction.

Any interpretation of sentencing patterns from the CSCCC papers is complicated by a highly significant change in the sexual offenses legislation that was introduced during the emergency. Back in 1926, white settler anxieties about the threat posed to white women in Kenya from sexual assault by black males led the colonial governor to introduce legislation

23. This complaint was lodged in April 1957, emanating from a detainee using the pseudonym Njiri Magothe. The complainant alleged that she had been sexual assaulted by four female prison warders at Kirigiti, who inserted a broken bottle into her vagina causing lacerations. Njiri also experienced a broken collarbone as a consequence of this assault. The deputy director of prosecutions instructed that this injury be investigated, but ignored the sexual assault. No judicial action was ultimately taken in this case, and the investigation was closed on September 2, 1957: TNA FCO 141/5668, minutes of CSCCC, September 1957. Elkins, Britain's Gulag, 206-15, 220-21, quotes extensively from similar letters.

24. These are listed sequentially in the minutes of meetings as cases are reported: see TNA FCO 141/6567 and TNA FCO 141/6568. Aside from the fifty-six cases recorded in the minutes, two other cases for which there is no further evidence are listed in TNA FCO 141/6209, Governor Evelyn Baring to Secretary of State for the Colonies, February 2, 1956. 
making rape a capital offence, meaning that such cases could only be heard before the Supreme Court. ${ }^{25}$ The penal sanctions then put in place were still in force at the beginning of the Kenyan Emergency in 1952: Article 133 of the Kenya Penal Code asserted that "any person who commits the offence of rape is liable to be punished with death or with imprisonment for life, with or without corporal punishment," while Article 134 extended the liability of life imprisonment to those found guilty of attempted rape. ${ }^{26}$

At the time this law was passed in 1926, legal officers in London had expressed concerns about this extension of the death penalty; however, similar legislation was then adopted by Nyasaland and Northern Rhodesia. These three colonies, along with the High Commission Territories of Southern Africa, were the only legislatures within the British Empire that retained this punishment for rape into the $1950 \mathrm{~s}^{27}$ Concerns were raised with these colonies and territories again in 1951, when the Colonial Office in London instituted a review of capital offenses, but the administration in Kenya was unwilling to make any change to the law. ${ }^{28}$ The matter came up again in 1955, this time by a vote in the British Parliament to abolish the death penalty. In reaction to this, Labour MP Anthony Wedgwood Benn tabled a parliamentary question asking to know the extent of capital punishment in the British Empire. It took the Colonial Office nearly 9 months to gather up the relevant information from the fortysix legislatures concerned in order to answer this question. ${ }^{29}$ While this investigation was still going on, in November 1955, the Kenyan administration "quietly" amended the Penal Code to lessen the penalties for rape. Since being passed into law, the death penalty had only rarely been handed down in rape cases, most recently in 1950 when three Africans were hanged for the rape of an elderly white woman. ${ }^{30}$ From December 1955 , rape allegations no longer needed to go before the Supreme Court, and

25. David M. Anderson, "Sexual Threat and Settler Society: Black Perils in Kenya, c.1907-1930," Journal of Imperial \& Commonwealth History 38 (2010), 47-74.

26. Laws of Kenya 1948, Penal Code Chapter XV, 218-19. The law was applied in a heavily racialized manner, as Anderson, "Sexual Threat and Settler Society" makes clear.

27. TNA CO 859/636, minute by Abrahams, January 31, 1955; TNA DO 35/7368, "Memorandum on Capital Punishment in High Commission Territories," October 1958.

28. TNA CO 859/636, "Summary of History," R. Turrell, January 24, 1955,

29. TNA CO 859/637 "Capital Punishment and Replies to Circulars 1954-56" contains details of the parliamentary question and collated details of the replies from all forty-six colonies, protectorates, and territories.

30. TNA CO 859/636, "Summary of history"; and J.K. Thompson to Fowler, March 10, 1956. See Brett Shadle, "Rape in the Courts of Gusiiland, Kenya, 1940s-1960s," African Studies Review 51 (2008), 27-50, for a general discussion of the operation of the law in Kenya. 
could be heard before a magistrate in a lower court, applying a much lower tariff of penalties to those convicted. ${ }^{31}$

Of the seventeen rape cases in which convictions were recorded by the CSCCC, in nine cases the sentences were handed down before this change. These cases heard before the end of 1956 were certainly not prosecuted with the full force of the law, and the change in legislation might be seen to reflect the reluctance of the Supreme Court judges to hand down harsh sentences for rape in the context of wartime. The reduction in the rate of conviction from 1956 also perhaps suggests that magistrates, too, were unwilling to tackle such cases with vigor. Throughout the emergency years, the sentencing of Africans by British judges and magistrates almost certainly reflected their belief that rape was not held to be a serious offense by Kenya's indigenous peoples, a matter to which we will return at the end of this article. ${ }^{32}$

The case investigation and prosecution figures collated from the papers of the CSCCC are summarized in Table 1. We will now consider in greater detail the wider context of the rape allegations reflected in these figures from the CSCCC papers for three categories of security services: the military, the Kikuyu Home Guard, and the police.

\section{Rape Allegations Against The Military}

The military had the most complex attitude to the investigation of rape cases. In the early phase of the emergency, from October 1952 through December 1953, abuses by the security forces were widespread. Kikuyu women fleeing into Nairobi in November 1952, to avoid the flare up of conflict in the rural areas, told the first stories of rape and assault by police officers and the military. ${ }^{33}$ By March 1953, intelligence reports candidly admitted that soldiers were involved in "inevitable pilfering and molesting of women" in operations against the civilian population. ${ }^{34}$

When General George Erskine arrived in Kenya in June 1953 to take command of the military he was shocked by this ill-discipline, and issued

31. Kenya Hansard, Legislative Council Debates, November 3, 1955, cols. 575-77, 618-20; and Shadle, "Rape in the Courts of Gusiiland," 27-50.

32. The general treatment of rape cases in Kenya reflects the wider tendency toward "administrative justice" in British colonial Africa. See, for example, Henry F. Morris and James S. Read, Indirect Rule and the Search for Justice (Oxford: Clarendon Press, 1972); and Martin Chanock, Law, Custom and Social Order: the Colonial Experience in Malawi and Zambia (Cambridge: Cambridge University Press, 1985).

33. TNA FCO 141/5724, "Political Intelligence Report-November 1952, Nairobi District, December 4, 1952".

34. TNA FCO 141/5733, "Laikipia Special Intelligence Report, March 15, 1953." 
Table 1. Rape Cases Reported by the Chief Secretary's Complaints Coordinating Committee, March 1954 to November 1959.

\begin{tabular}{|c|c|c|c|c|c|c|c|c|c|c|c|c|c|}
\hline & \multicolumn{7}{|c|}{ Year } & \multicolumn{6}{|c|}{ Outcome } \\
\hline & 1954 & 1955 & 1956 & 1957 & 1958 & 1959 & Total & $\begin{array}{l}\text { No } \\
\text { Case }\end{array}$ & Convict & Acquit & NP & Insane & Unknown \\
\hline \multicolumn{14}{|l|}{ Military } \\
\hline British Army & 1 & 1 & - & - & - & - & 2 & 1 & 1 & - & - & - & - \\
\hline King's African Rifles & 4 & - & - & 1 & - & - & 5 & 4 & 1 & - & - & - & - \\
\hline Kenya Regiment & 1 & 1 & - & - & - & - & 2 & - & 1 & 1 & - & - & - \\
\hline \multicolumn{14}{|l|}{ Police and Prisons } \\
\hline Kenya Police & 3 & 5 & 5 & 8 & 1 & 1 & 23 & 12 & 6 & 5 & - & - & - \\
\hline Kenya Police Reserve & - & 2 & 1 & - & - & - & 3 & 2 & 1 & - & - & - & - \\
\hline Prisons & - & 2 & - & 1 & - & - & 3 & 2 & - & - & - & - & 1 \\
\hline \multicolumn{14}{|l|}{ Administration } \\
\hline Home Guard & - & 4 & 5 & 1 & - & - & 10 & - & 5 & 3 & 1 & - & 1 \\
\hline Tribal Police & - & 1 & 1 & 3 & 1 & - & 6 & 2 & 2 & 1 & - & 1 & - \\
\hline Screening Officers & 1 & - & - & - & - & - & 1 & 1 & - & - & - & - & - \\
\hline Unknown & - & 1 & - & - & - & - & 1 & - & - & - & - & - & 1 \\
\hline Totals & 10 & 17 & 12 & 14 & 2 & 1 & 56 & 24 & 17 & 10 & 1 & 1 & 3 \\
\hline
\end{tabular}


a warning to his soldiers that allegations made against them "would be properly investigated." 35 This turned out to be a hollow claim: Erskine's principal aim was to protect the reputation of the army, and although that did imply preventing abuses, it also involved minimizing the adverse publicity such cases attracted and the negative effects they had on service morale. Erskine, therefore, secured an agreement from the attorney general that cases involving soldiers would be heard before military courts, and would not go before civilian magistrates. ${ }^{36}$ The extent to which the military then pursued those investigations would not be subject to scrutiny, other than the process of cases being reported to the CSCCC.

Military reluctance to open up rape allegations to criminal investigation was vividly seen in the inquiry by Lieutenant-General Sir Kenneth MacLean into the conduct of the British Army in Kenya, held in closed sessions in Nairobi during December 1953. The terms of reference of this inquiry were restricted to the period of Erskine's command, meaning that Lieutenant-General Sir Kenneth MacLean was barred from investigating any reported incident that took place before July 1953. Soldiers giving evidence to MacLean had to be repeatedly reminded of this general restriction. Moreover, the MacLean inquiry refused to pursue the mentions of rape that were made in evidence, even telling one witness "That is not the sort of thing we are concerned with." 37 Despite the fact that the Army Act categorized rape as a serious offense, bracketing it alongside murder and manslaughter, a senior officer in the military police told the MacLean inquiry that in Kenya, the army treated rape as "a minor crime," in the same category as theft. Whenever rape was committed alongside other offenses, it was usual for the rape charges to be ignored, especially if those other offenses were deemed more serious. This was most glaring in the notorious case at Chuka in June 1953, when rapes by African soldiers of the King's African Rifles and their two British officers led to a confrontation with villagers in which twenty-two Kikuyu were killed. Compensation was paid to the families of the deceased, but no public mention was made of the rapes that ignited the incident, and the military took active steps to suppress information about the event being released. ${ }^{38}$

35. Anderson, Histories of the Hanged, 259. For the full text of Erskine's statement, see TNA CO 822/474.

36. The point is made by Bennett, Fighting the Mau Mau, 206, drawing on TNA CO 968/ 424, War Office to Rogers (Colonial Office), September 12, 1953. (This file was also part of the Hanslope Disclosure.)

37. TNA WO 32/31720, MacLean Court of Inquiry Proceedings, 316.

38. TNA FCO 141/6193, "Kenya; Mau Mau Unrest - Chuka Incident, 1953-1956." This military response was justified in operational terms, but reflected wider colonial perceptions of African sexuality. For a highly insightful discussion of this, see Shadle, "Rape in the 
These features of the handling of rape allegations by the military explain why so few were referred to the CSCCC, with only nine cases being reported over a 6 year period. The majority of these cases, six in all, arose in 1954, four being allegations of gang rape by African soldiers of the King's African Rifles. These gang rape cases all followed a similar pattern of investigation, each being reported first through the C.I.D. and passed on to the military authorities, who then showed a remarkable reluctance to proceed. Repeated requests from the CSCCC for reports on investigations were ignored, or excuses were offered. These investigations lay with the military without resolution for periods of longer than 6 months, and in one case for more than a year. In all four gang rape cases, military investigators ultimately declared that there was insufficient evidence to identify the culprits, and, therefore, the cases were all dropped without judicial action. ${ }^{39}$

However, a fifth case of gang rape, also from 1954, was handled very differently. This concerned three British soldiers of the Royal Engineers, who were prosecuted by courts-martial and convicted, with each being sentenced to 6 years' imprisonment. ${ }^{40}$ These were the harshest sentences handed down to any person convicted of rape during the Kenyan Emergency, and, in marked contrast to the delays in the four King's African Rifles gang rape cases, only 8 weeks elapsed between the notification of this case and the sentencing of the convicts. Evidently, the army could move swiftly enough when it wanted to. The remaining military rape case from 1954 was an allegation against an individual soldier of the Kenya Regiment, a white settler. This case was also rapidly processed, there being only 4 weeks between the notification of the case and the courtmartial hearing, at which the soldier was acquitted.

The archive documents do not offer an explanation for the differences in processing the four King's African Rifles cases and the two cases concerning British accused from 1954, but there is an obvious racial distinction: those cases involving white soldiers were hurried through the military courts, whereas those involving black African soldiers were the subject of delay, prevarication, and, ultimately, deflection. The reason for this almost certainly lies in the contrast between the prevailing attitudes of the locally recruited King's African Rifles, whose commanders dismissed rape as a trivial offense, whereas General Erskine sought to protect the British Army

Courts of Gusiiland," 28-31, and (more broadly) Pamela Scully, "Rape Race, and Colonial Culture: The Sexual Politics of Identity in the Nineteenth-Century Cape Colony, South Africa," American Historical Review 100 (1995), esp. 336-39.

39. TNA FCO 141/6567, minutes of meetings of CSCCC, between July 26, 1954 and September 1955.

40. TNA FCO 141/6567, minutes of CSCCC, from September 6 to November 6, 1954. 
regiments from further reputational damage by ensuring that such cases involving British soldiers were "properly investigated." It is difficult, therefore, to avoid the conclusion that the pattern of prosecutions had a racial aspect: rape allegations made against African rank and file were processed in a different way than those made against white soldiers of all ranks, because different standards of behavior were applied by the military.

This view is borne out by the remaining three cases involving military personnel, spanning 1955 to 1957. The first, from May 1955, saw a soldier of the Royal Engineers accused of sexual assault against a child at the town of Thika. Again, this case against a British soldier was rapidly investigated over a period of 5 weeks and a decision was made not to prosecute, because of contradictory evidence. One month later, an officer of the Kenya Regiment was committed for court-martial after another very speedy investigation by military officers. He was convicted of indecent assault and discharged with ignominy after 6 months' military detention. In the final military case recorded by the CSCCC, from January 1957, an African private from the King's African Rifles was convicted of the attempted rape of a civilian woman as she was leaving the Langata military camp. This case, having occurred in a nonoperational context and in civil jurisdiction, and coming after the changes made to the penalties for rape in Kenya, went before the magistrate's court in Nairobi, where the convict received a custodial sentence of 12 months. Remarkably, this is the only case recorded of the conviction for rape or sexual assault of an African in the military during Kenya's Emergency.

\section{Rape Allegations Against Kikuyu Home Guard (Militia)}

The Home Guard features prominently in accusations of sexual abuses in oral testimonies and memoirs on the Kenya Emergency, although they were very rarely prosecuted. They fitted the classic pattern described by Raphaelle Branche in her study of rape in the Algerian War of the 1950s, as having "opportunity" for sexual crimes, but also enjoying a kind of impunity. ${ }^{41}$ In the first phase of the war, over 1953 and 1954, "screening" (interrogation) of civilians, including many women suspects, was conducted by the Home Guard, who from 1955 then dominated the implementation of the villagization program. ${ }^{42}$ Resettlement in these

41. Raphaëlle Branche, "Des Viols Pendant La Guerre d'Algérie," Vingtième Siècle. Revue D'histoire 75 (2002), 126.

42. M.P. Keith Sorrenson, Land Reform in the Kikuyu Country: A Study in Government Policy (Nairobi: Oxford University Press, 1967). Elkins, Britain's Gulag, reports many abuses in the villagization program. See also Branch, Defeating Mau Mau, 107-16. 
newly constructed villages brought enhanced security to the rural area and put the Home Guard formally in charge of the entire Kikuyu population, a population whose gender balance was hugely distorted by the conditions of the Emergency. In the only village studied in depth at the time, Kabare, the population numbered 1,360 , but included only 176 adult males. ${ }^{43}$ In the villagization process, therefore, the wives and other female relatives of known Mau Mau activists were especially vulnerable. According to Daniel Branch, "abuses committed by the Home Guards were widespread in the villages." 44 In 1954, one district officer candidly admitted that the Kikuyu militia under his charge were "genuine out and out thugs, and are probably guilty of far more than is reported." 45 The abduction and sexual assault of women were among the crimes of which they were regularly accused. As a senior police officer conceded in December 1954, the Home Guard had come to possess "the power of life and death." "Bribery and corruption" were "rife," he continued, and "acts of murder, rape, arson, robbery and extortion" had been "directed against the local population." 46

Rape cases recorded by the CSCCC in which the accused were members of the colonial administration, including the Home Guard, came under civil jurisdiction, and, therefore, were not subject to courts-martial. The administrative procedures adopted for processing these civil cases allowed considerable scope for delay, deflection, and even the suppression of investigations. Inordinate delays in gathering evidence were common, and even where criminal investigations had been fully conducted by the police, the CSCCC was empowered to ask that a further "preliminary investigation" (PI) be conducted in order to establish whether there was a case to answer. A PI might be conducted by a resident magistrate if one were available, but in most locations where offenses took place, the only persons holding magisterial powers were those European administrative officers of the rank of district officer and district commissioner. This conflation of legal and administrative roles was a critical element in the conduct of such investigations. European officers placed in charge of Home Guard posts, many of whom were on service with the military (notably the Kenya Regiment), were also given the rank of district officer and,

43. KNA DC/EBU/9/1, Greet Sluiter, "A Study of Kabare Village in the Embu District," May 1956.

44. Branch, Defeating Mau Mau, 109-10.

45. KNA DC/KBU/2/1, DO Gatundu, "Gatundu District Handing Over Report," September 6, 1954, 11.

46. TNA FCO 141/6207, K.P. Hadingham (Asst. Commissioner of Police, Nyeri) to Provincial Commissioner, Central Province, December 14, 1954. 
therefore, held the powers of a magistrate, even though they were unlikely to have had any training in this capacity. ${ }^{47}$

In practice, therefore, PIs were frequently conducted by colleagues of the accused, or even by their commanding officers: for example, the district officer commanding a Home Guard post might oversee the PI into an accusation against his own Home Guard militiamen. Although some members of the colonial administration reported offenses and cooperated in these investigations, the prevailing view was that such prosecutions were harmful to the morale of the security services and undermined the counterinsurgency campaign, especially among African auxiliaries. ${ }^{48}$ Not surprisingly, then, in many cases, the delays and lack of clear evidence adduced by the PI appeared to have been more helpful to the accused than to the prosecution. In rape cases listed by the CSCCC, PI investigators frequently claimed that witnesses could not be found, that statements gathered were contradictory and therefore unlikely to support conviction, that culprits could not be satisfactorily identified, or that they could not obtain medical evidence to support the allegations. Any one of these failings might be held as a suitable reason to dismiss the case without going to court. In the worst cases, there were proven examples of malicious interference with PIs, and of perjury committed by witnesses to protect the accused from prosecution and conviction. ${ }^{49}$

The influence that district administrators held over PIs made it more difficult for rape cases to be brought against Kikuyu Home Guard than against any other arm of the security services. Among the fifty-six rape cases reported in the papers of the CSCCC, only ten concern allegations against Kikuyu Home Guard. Political considerations also played a significant role in determining how these cases were handled, and may partly explain why so few appear in the minutes of the committee. An amnesty brought into force by decree of the Governor, Evelyn Baring, in January 1955, halted inquiries into allegations made against members of the colonial administration, which were then under investigation. ${ }^{50}$ Cases against the Home Guard recorded by the CSCCC, therefore, exclude any from 1954, a year in which the battle between the Home Guard and Mau Mau supporters in the Central Province was at its peak and when a bulge in allegations of all kinds of

47. Colony \& Protectorate of Kenya, History of the Loyalists (Nairobi: Government Printer, 1961).

48. Anderson, "British Abuse and Torture," 714-18; and Bennett, Fighting the Mau Mau, $210-11$.

49. See, for examples, TNA FCO 141/6510, "Kenya; Disciplinary Action-Mr. H.W. Richmond, DO'; and TNA FCO 141/6209, "Kenya: Complaints Against Security Forces."

50. TNA FCO 141/6200, "Kenya: Mau Mau Unrest - Offer of Amnesty, 1955-56," and TNA FCO 141/5684, "Kenya: Mau Mau Unrest-Offer of Amnesty, 1955." 
abuse might have been expected. Instead, the cases mentioned by the CSCCC cluster in a less active period, between March 1955 and the early months of 1957, when Home Guard numbers were being reduced and greater discipline was being brought to bear on the militia. ${ }^{51}$

Political influence can also be seen in the outcome of prosecutions of the Home Guard. In two cases from early 1955, in the months just following the amnesty and during a period when the colonial authorities were especially keen to be seen to act against such offences, those convicted were sentenced to 5 and 6 years' imprisonment, respectively, both with hard labor. Other than the gang rape case against the three British soldiers of the Royal Engineers, these two convictions carried the harshest sentences of any rape cases during the Emergency. ${ }^{52}$

It is also significant that in five of the ten cases listed against the Home Guard the accused were headmen. These African officials, appointed under chiefs in order to manage the affairs of locations and sublocations, were crucial actors in the battle against the Mau Mau passive wing, ${ }^{53}$ giving leadership to loyalist communities and acting as commanders of Home Guard units. Although there were many notable cases of proven abuse by these headmen, ${ }^{54}$ government officials feared that Mau Mau supporters deliberately targeted such men, and that allegations made against them might be malicious. It was, therefore, usual for British colonial officials to "rally round" any headman accused of abuse, and, in such cases, the colonial government paid for their legal defense, something that Attorney General Eric Griffiths-Jones argued against but failed to prevent. ${ }^{55}$ The pursuit of allegations against African headmen may, therefore, have reflected the determination of Mau Mau's passive wing to expose the abuses of such people; however, the fact that all five of these allegations came to court suggests that district officials had been unable, or unwilling, to mobilize to thwart the charges.

Victims of rape at the hands of Home Guard may, therefore, have faced many obstacles in bringing cases to official notice, as well as having many reasons to keep silent. Unlike the soldiers and police in the CSCCC cases who were "strangers," for the most part, Home Guard operated among their own community, and any assailants would be likely to be known to their

51. Branch, Defeating Mau Mau, 115-16.

52. TNA FCO 141/6567 and TNA FCO 141/6568.

53. "Passive wing" as the term used to denote noncombatant supporters of Mau Mau within the population of the Kikuyu Reserves of Central Province.

54. For the most infamous example, at Ruthagathi, see Anderson, Histories of the Hanged, 297-306.

55. TNA FCO 141/6174, Griffith-Jones (Solicitor General) to K.M. Cowan (Ag Chief Native Commissioner), December 15, 1953. 
victims. What we know about other abuses perpetrated in Home Guard posts, such as beatings and extortion, strongly suggests that these actions were perceived as punishments to be deservedly inflicted upon rebels and their supporters. For the vast majority of victims, there could have seemed little point in pursuing legal remedies in these circumstances. Rapists among Home Guard may have behaved opportunistically with regard to the wives, daughters, and sisters of known Mau Mau activists, but they were also inflicting punishment on an intimate enemy and at the same time marking the exclusion of that person and that person's family from the accepted norms of Kikuyu social life: Mau Mau were outcasts who forfeited their property and their rights. Even when punishment was opportunistic, it was also strategic.

It is also possible that the Kikuyu families of the victims of rape at the hands of Kikuyu Home Guard may have viewed social remedies as a preferred alternative to legal procedures. In her work on rape in twentieth century African conflicts, Meredith Turshen contends that rape is most often seen as an economic rather than a moral matter, and that its settlement usually requires compensatory payments to the wider family of the victim. ${ }^{56}$ This separation of economic and moral aspects must be questioned for many parts of Africa, and Brett Shadle has provided compelling evidence from another part of Kenya, Gusiiland, to indicate that this was not invariably true even within colonial Kenya. ${ }^{57}$ Social remedies might combine both economic and moral aspects. Historian Tabitha Kanogo describes rape and other forms of sexual assault as having known and wellunderstood social remedies within Kikuyu society, both economic and moral, imposed through community sanction against those who infringed the accepted norms. ${ }^{58}$ As Kanogo explains, when a rape occurred "it was the clan that was perceived to be the aggrieved party to be appeased, for the woman had no individual standing in the matter, cultural or legal," 59 whereas Claire Robertson concludes that rape among Kikuyu was primarily considered as a violation of property. ${ }^{60}$ In the 1950 s, social

56. Meredith Turshen, "The Political Economy of Rape: An Analysis of Systematic Rape and Sexual Abuse of Women During Armed Conflict in Africa," in Victims, Perpetrators or Actors? Gender, Armed Conflict and Political Violence, ed. Caroline O.N. Moser and Fiona C. Clark (London: Zed Books, 2001), 55-68.

57. Shadle, "Rape in the Courts of Gusiiland."

58. Tabitha Kanogo, African Womanhood in Colonial Kenya, 1900-1950 (Oxford; James Currey, 2005), 55-64.

59. Kanogo, African Womanhood, 55.

60. Claire Robertson, Trouble Showed the Way: Women, Men and Trade in the Nairobi Area, 1890-1990 (Bloomington: Indiana University Press, 1997). 
remedies, in the form of a tariff of compensation payable by those culpable to the family of the victim, still remained open to any Kikuyu.

The existence of accepted social remedies in cases of rape may have deterred victims from seeking legal redress through the courts; however, the breakdown of social order that the Emergency brought to Kikuyu areas made it unlikely that such sanctions could be enforced, least of all if the victims of the abuse were perceived to be rebels and, therefore, outcasts. This is not a matter to which the archival documents speak, but it is clearly an issue that other research might address in deepening understanding of the response to rape and other sexual crimes in colonial Central Kenya.

\section{Rape Allegations Against Police}

The majority of rape cases recorded by the CSCCC concerned allegations against the various branches of the police: twenty-three cases against the Kenya Police, three cases against Kenya Police Reservists, and six cases against Tribal Police. With the exception of the Tribal Police, who were normally recruited and worked in their home areas, under the control of the local African chief, the police in 1950s Kenya were strangers to the communities whom they worked among. The Emergency had seen a dramatic and rapid increase in the presence of the Kenya Police in the Kikuyu areas of Central Province. On the eve of the rebellion, in October 1952, there had been only four police stations in all of the Kikuyu areas. Fifteen months later, by the end of 1953, there were more than sixty police stations there, every location having at least one police post and many having two. Over this same period, 3,200 additional Africans were recruited into the Kenya Police, but as it was considered "too risky to attempt to recruit Kikuyu," these reinforcements were all drawn from other ethnic groups. By December 1953, of 9,850 Africans in the Kenya Police, only 178 were Kikuyu. ${ }^{61}$

For the Kikuyu population, the Kenya Police therefore appeared as an alien army of occupation: militarized, heavily armed, and based in newly constructed fortified posts dotted throughout the countryside. A commission set up to look at the impact of the rapid expansion of the force commented in 1953 that the Kenya Police had been trained "to act as squads of men operating in hostile surroundings where their first instinct is to use their rifles." ${ }^{\circ 2}$ By design, this was a very intrusive and aggressive kind of policing, sculpted to the purposes of wartime Kenya.

61. David Throup, "Crime, Politics and the Police in Colonial Kenya, 1939-63," in Policing and Decolonisation: Nationalism, Politics and the Police, 1917-65, ed. David M. Anderson and David Killingray (Manchester: Manchester University Press, 1992), 141.

62. Stephen J. Baker and William A. Muller, Report of the Kenya Police Commission, 1953 (Nairobi: Government Printer, 1953), 6-7. 
The character of the rape cases brought against the police is remarkably consistent. Nearly all these alleged assaults occurred within a police station, or in police vehicles, the women having been apprehended on some minor offense or on suspicion. The majority of the allegations concerned rape by two or three police officers together: twelve of the twentysix cases concerning Kenya Police and Kenya Police Reserve had a lone assailant, and fourteen had multiple perpetrators. In only two cases with a single assailant was a conviction achieved, the other cases most often being thrown out at the PI because of contradictory evidence and the lack of independent witnesses.

The circumstances of police work during the Emergency created many opportunities for the sexual abuse of women, groups of police often having custody of single females in places of confinement and without other witnesses present. The allegation of a Kikuyu woman, arrested in the Eastlands area of Nairobi in April 1957 and taken to the police station in the industrial area, is typical of these cases. She was questioned and then detained in a cell overnight, whereupon the one police officer on night duty at the station entered her cell and forcibly raped her. Without medical evidence to substantiate her claims, and with no other witnesses to the offense, in the face of the police constable's outright denials the PI found there to be "insufficient evidence" to merit a trial. The CSCCC therefore approved the case to be dismissed. Many cases from the rural areas were similar. A woman taken in for questioning by two police constables near Gathithi village in Nyeri district, for example, alleged that she was raped in the back of the police Land Rover before being returned to her home. Despite her picking out one of the assailants in an identification parade, the case was dismissed because of lack of corroboratory evidence.

In the one allegation brought against two European police officers accused of raping two Kikuyu women while they were in custody at Githuro Police Station in October 1956, the case came to trial and the accused were acquitted. Beyond this one case involving white officers, there is no record of the ethnicity of the police officers against whom rape allegations were made; however, the low numbers of Kikuyu in the Kenya Police indicates that the accused men were likely to be strangers to the local Kikuyu communities. Kikuyu victims had no obvious means to seek a social remedy for rape committed by persons of another ethnicity; therefore, a formal complaint aimed at the colonial courts was more likely against an assailant from the police force than it was in the case of rape by members of the Kikuyu Home Guard.

The "stranger" factor may then explain the larger number of formal legal allegations recorded against police, but other trends are more clearly apparent in the sample of cases we have from the CSCCC. Of the thirty-two 
allegations brought against members of the three police services, sixteen $(50 \%)$ were dismissed without coming to trial, nine resulted in convictions, there were six acquittals, and one accused was sent for trial but declared insane. The tactics of delay and deflection described for military and Home Guard allegations were also evident in these cases. From such a small sample, it is difficult to draw general conclusions, but it must be noted that over time a smaller proportion of rape allegations against police came before the courts; of the fourteen allegations recorded for 1955 and 1956, eleven went to trial, whereas from 1957 to 1959 only three out of fourteen alleged assaults were prosecuted. The same temporal shift is evident in convictions. From January 1956 to November 1959, the CSCCC recorded sixteen cases against Kenya Police and Kenya Police Reserve, only one of which resulted in a conviction. The ten cases recorded up to December 1955 saw six convictions.

These trends appear to reflect the ebb and flow of the war itself. Of the seventeen rape cases in which convictions were achieved, only one came before the amnesty of January 1955. In the 11 months following the amnesty, when the state showed a greater determination to enforce discipline on the security services, there were ten convictions. Decisions to prosecute, and even the behavior of the courts in handing down sentences in rape cases, were therefore strongly influenced by the political fluctuations of the conflict.

\section{Discussion: Rape in Wartime, c. 1940-70s}

After many years of turning a blind eye to sexual crimes in wartime, over the past decade, historians have rediscovered the prevalence and significance of rape as a weapon of war. This reawakening has owed much to the shift in international law that has seen mechanisms developed in international courts for the prosecution of rape as a specific war crime, ${ }^{63}$ particularly in response to the use of sexual assaults in the Balkans wars of the

63. Jocelyn Campanaro, "Women, War and International Law: The Historical Treatment of Gender-Based War Crimes," Georgetown Law Journal 89 (2000), 2557-79, and Mark Osiel, Obeying Orders: Atrocity, Military Discipline, and the Laws of War (Edison: Transaction Publishers, 1999). See also, Neil Mitchell, Agents of Atrocity: Leaders, Followers, and the Violations of Human Rights during Civil War (New York: Palgrave Macmillan, 2004); and A. Hoover Green, "Statistical Evidence of Sexual Violence in International Court Settings," in Understanding and Proving International Sex Crimes, ed. Morten Bergsmo, Alf Butenschon Skre, and Elisabeth J. Wood (Oslo: Torkel Opsahl Academic Epublisher, 2012), 294-314. 
$1990 \mathrm{~s},{ }^{64}$ and in the Rwanda genocide and the Congo wars that it gave rise to from $1994 .^{65}$

Half a century earlier, at the end of the Second World War, there had been a similar awareness of rape in wartime, but also an apparent reluctance to prosecute for sexual crimes. In April 1946, when the International Military Tribunal for the Far East documented the infamous "Rape of Nanking" of December 1937, estimating that approximately 20,000 women had been the victims of systematic military rapes by the Japanese army, the senior officers held responsible were charged for a generality of alleged acts "carried out in violation of recognized customs and conventions of war ... [including] mass murder, rape, ... and other barbaric cruelties," and not for specific sexual crimes. ${ }^{66}$ The 1949 Geneva Convention was also explicit in enumerating rape as a distinct violation, with Article 27 stating that women are "protected against any attack on their honour, in particular against rape, enforced prostitution, or any form of indecent assault"; ${ }^{67}$ however, this was seldom treated discretely

64. Todd A. Salzman, "Rape Camps as a Means of Ethnic Cleansing: Religious, Cultural, and Ethical Responses to Rape Victims in the Former Yugoslavia," Human Rights Quarterly 20 (1998), 348-78; Human Rights Watch, Bosnia-Hercegovinia, "A Closed, Dark Place": Past and Present Human Rights Abuses (New York: Human Rights Watch, 1998); and Beverly Allen, Rape Warfare: The Hidden Genocide in Bosnia-Herzegovinia and Croatia (Minneapolis: University of Minnesota Press, 1996).

65. Human Rights Watch, Shattered Lives: Sexual Violence during the Rwanda Genocide and its Aftermath (New York: Human Rights Watch, 1996); Human Rights Watch, Soldiers Who Rape, Commanders Who Condone: Sexual Violence and Military Reform in the Democratic Republic of Congo (New York: Human Rights Watch, 2009); Maria Baaz and Maria Stern, The Complexity of Violence: a Critical Analysis of Sexual Violence in the Democratic Republic of the Congo (Uppsala: Nordic Africa Institute, 2010); and Catrien Bijleveld, Aafke Morssinkhof, and Alette Smeulers, "Counting the Countless: Rape Victimization During the Rwanda Genocide," International Criminal Justice Review 19 (2009), 208-24. Sierra Leone has also become an important case-see Zoe Marks, "Sexual Violence in the Sierra Leone Civil War: 'Virgination', Rape and Marriage," African Affairs 113 (2014), 67-87; and Dara K. Cohen, "Explaining Sexual Violence During Civil War" (PhD diss., Stanford University, 2010).

66. Campanaro, "Women, War, and International Law," 2563. Iris Chang, The Rape of Nanking: The Forgotten Holocaust of World War II (New York: Penguin, 1997); and Karen Parker and Jennifer F Chew, "Compensation for Japans' World War II War-Rape Victims," Hastings International and Comparative Law Review 17 (1993), 497-549, discuss the delay in recognition for these victims. On Japanese institutionalized prostitution, see Yoshiaki Yoshimi, Comfort Women, expanded 2nd ed. (New York: Columbia University Press, 2002); and George L. Hicks, The Comfort Women: Japan's Brutal Regime of Enforced Prostitution in the Second World War (New York: WW Norton, 1997).

67. Darren Anne Nebesar, "Gender-Based Violence as a Weapon of War," University of California Davis Journal of International Law and Policy 4 (1998), 160. 
by lawyers in prosecuting war crimes over the following years, until the 1990s.

As Cynthia Enloe's pioneering work on militarism and gender indicated, ${ }^{68}$ this did not imply that military commanders accepted or adopted the terms set out by the Geneva Convention. Rather, Enloe described the means by which the military "maneuvered" rape victims into distinct civilian categories that sought to minimize or exonerate the stigma attached to their crime: the military deployed rape, she argued, to assist in their own military causes. The segregation of rape perpetrators in 1950s Kenya into different institutional and racial categories can thus be seen as an illustration of Enloe's central argument. ${ }^{69}$

The reluctance to prosecute rape in Kenya in the 1950s was not, then, because of a lack of awareness of the significance of rape in wartime; however, it does fit with a broader pattern of denial from this period. As Susan Brownmiller reminds us in her powerful and pioneering commentary on the instrumental character of rape in the Pakistan army's invasion of Bangladesh in 1971, where an estimated 300,000 civilian women were raped by soldiers, ${ }^{70}$ contemporary evidence on rape in conflicts from the twentieth century is not difficult to come by: very often, we have known about it at the time. In September 1945, Time Magazine candidly told its readers that in the Allied assault on Berlin "Our own army and the British army along with ours have done their share of looting and raping ... we too are considered an army of rapists." 71

For the Vietnam War, too, after three decades of "official amnesia," we now have Gina Weaver's 2010 monograph on rape and the United States Army. ${ }^{72}$ Alarmed by American silence over these sexual crimes, Weaver nonetheless located "volumes of testimony" on "America's dirty secret," including the "horrific and detailed accounts of sexual violence" from United States Army veterans recorded in the Winter Soldier Investigation

68. Cynthia Enloe, Bananas, Beaches and Bases: Making Feminist Sense of International Politics (London: Pandora, 1989).

69. Cynthia Enloe, Maneuvers: The International Politics of Militarizing Women's Lives (London: University of California Press, 2000).

70. Susan Brownmiller, Against Our Will: Men, Women and Rape (New York: Simon \& Schuster, 1975), 14. For the deeper complexities of the Bangladeshi case, see Nayanika Mookherjee, "Denunciatory Practices and the Constitutive Role of Collaboration in the Bangladesh War," in Traitors: Suspicion, Intimacy and the Ethics of State-Building, ed. Tobias Kelly and Sharika Thiranagama (Philadelphia: University of Pennsylvania Press: 2009), 48-67.

71. "Germany: Crackdowns," Time XLVI, September 17, 1945, quoted in Richard Drayton, "An Ethical Blank Cheque," The Guardian, May 9, 2005.

72. Gina Marie Weaver, Ideologies of Forgetting: Rape in the Vietnam War (Albany: State University of New York Press, 2010). 
of January 1971 and logged on the Congressional Record later that year. ${ }^{73}$ As journalist and historian Nick Turse has observed, America has known these things all along: so why, then, did it take 40 years for them to be written about and discussed? ? $^{4}$

Such "difficult" facts were largely ignored in the aftermath of wars, despite the gradual emergence from the 1950s onwards of a plethora of biographies and memoirs of victims and participants who described their experience of sexual crimes at the hands of one or another army in Europe during the $1940 \mathrm{~s},{ }^{75}$ and of the constancy of rape as a trope in literary and cinematic presentations of the Vietnam War from the 1970s onwards. ${ }^{76}$ The same was true in Kenya in the years following the end of the Emergency in 1960.

Despite the representation of rape in these portrayals of conflicts, victors' histories seem inevitably to have been silent on the subject of sexual violence until the 1990s. Returning to testimonies about sexual crimes in wartime from the 1990s onwards, and combining them with documentary evidence from the archives, historians have now begun to compile a startling account of the full extent and character of rape in modern conflicts. The story from the final phase of World War II in Europe has been especially grisly. Detailed studies of the prosecutions of Wehrmacht officers for sexual offences, including rapes, and harrowing accounts of the systematic rape of Jewish women before their murders, are now available. ${ }^{77}$ The atrocious behaviour of the German Army and their allies against the "lesser races" on the Eastern Front has long been understood, but the archives have revealed a chilling story of the systematic manner in which rape was used as a reprisal punishment by the Russian army as they advanced

73. Weaver, Ideologies of Forgetting, quotes at xii, xiv, and 5. For the Winter Soldier Investigation testimony, see http://www3.iath.virginia.edu/sixties/HTML_docs/Resources/ Primary/Winter_Soldier/WS entry.htm1 (April 4, 2013).

74. Nick Turse, "Rape was rampant during the Vietnam war. Why doesn't US history remember this?" Mother Jones, March 19, 2013, http://www.motherjones.com (March 21, 2013). See also his revisionist history, Kill Anything That Moves: The Real American War in Vietnam (New York; Metropolitan Books, 2013).

75. For an excellent introduction to such sources for World War II in Europe, see Jeffrey Burds, "Sexual Violence in Europe in World War II, 1939-1945," Politics \& Society 37 (2009), 35-73.

76. "Introduction," in Weaver, Ideologies of Forgetting.

77. Birgit Beck, Wehrmacht und sexuelle Gewalt: Sexualverbrechen vor deutschen Militargerichten 1939-1945 (Paderborn: Schoningh, 2004); and Birgit Beck, "Rape: the Military Trials of Sexual Crimes Committed by Soldiers in the Wehrmacht, 1939-44," in Home/Front: The Military, War and Gender in Twentieth Century Germany, ed. Karen Hagemann and Stefanie Schuler-Springorum (New York and Oxford: Berg, 2002). 
on Berlin. ${ }^{78}$ The sexual crimes of the Allied Armies on the Western Front have also now been examined in depth, most notably in criminologist J. Robert Lilly's forensic account of the prosecutions of some of those responsible for the rapes of an estimated 14,000 civilian women by members of the United States Army in Western Europe between 1942 and 1945. ${ }^{79}$

In all of these conflicts, from Europe in the 1940s to Bangladesh in the 1970s, there was some element of contemporaneous investigation and prosecution of rape cases, but, as in Kenya, this was everywhere highly selective and partial. Although the fact of rape could not be denied, sexual crimes could be deflected and diminished. When prosecutions did occur, they tended to reflect racial and status sensibilities. Wehrmacht prosecutions were most obviously determined by such factors: German soldiers were prosecuted for threatening racial purity. ${ }^{80}$ But Lilly's account of the racial pattern of prosecutions and sentencing of rapists within the United States Army indicates that black soldiers were more likely to feel the full force of the law than their white counterparts, and that rapes of German women were less likely to be prosecuted than those of women of Allied nationalities. ${ }^{81}$

Race and rank of perpetrators and victims mattered in shaping patterns of prosecution and conviction. ${ }^{82}$ The evidence from Kenya indicates that whereas the military were concerned to assert their own command over

78. Norman Naimark, The Russians in Germany: A History of the Soviet Zone of Occupation, 1945-1949 (Cambridge, MA: Belknap Press, 1995); and Catherine Merridale, Ivan's War: Life and Death in the Red Army, 1939-1945 (New York: Metropolitan Books, 2006). German sources are extensively used by Wendy Jo Gerjejanssen, "Victims, Heroes, Survivors: Sexual Violence on the Eastern Front During World War II" (PhD diss., University of Minnesota, 2004).

79. J. Robert Lilly, Taken By Force: Rape and American GIs in Europe during World War II (New York: Palgrave Macmillan, 2007). See also: Atina Grossmann, "A Question of Silence: The Rape of German Women by Occupation Soldiers," in West Germany Under Reconstruction: Politics, Society and Culture in the Adenauer Era, ed. Robert Moeller (Ann Arbor: University of Michigan Press, 1997), 33-52; and Perry Biddiscombe, "Dangerous Liaisons: The Anti-Fraternization Movement in the US Occupied Zones of Germany and Austria, 1945-48," Journal of Social History 34 (2001), 611-47.

80. Birgit Beck, "Sexual Violence and its Prosecution: Courts Martial of the Wehrmacht," in A World at Total War: Global Conflict and the Politics of Destruction, 1937-1945, ed. Roger Clickering (Cambridge: Cambridge University Press, 2006); and Patricia Szobar, "Telling Sexual Stories in the Nazi Courts of Law: Race Defilement in Germany, 19331945," Journal of the History of Sexuality 11 (2002), 131-63.

81. Lilly, Taken by Force, 91-94, 153-64.

82. For comparative studies of race and prosecution in the context of empire, see Elizabeth Kolsky, Colonial Justice in British India (Cambridge; Cambridge University Press, 2010); and, Martin J. Weiner, An Empire on Trial: Race, Murder and Justice Under British Rule, 1870-1935 (Cambridge: Cambridge University Press, 2007). 
rape cases, taking account of race and rank, the British civilian authorities veered strongly toward accommodation with their African allies, smoothing over the scandals and trying to sustain the morale of African "Loyalists." British colonial administrators came to view rape as an inevitable and largely inconsequential effect of the conflict, and were able to justify their passivity through their belief that Africans held the same opinion. The British military, on the other hand, vigorously pursued prosecutions against white soldiers and dismissed or deflected allegations against black soldiers. Both civilian and military attitudes were overtly racial, each invoking deeply ingrained and mythologized imperial notions of African sexuality and morals. ${ }^{83}$

In the context of colonial life in the post-Second World War years, white society in Kenya commonly believed that "Africans did not consider rape to be a serious crime." ${ }^{84}$ One of Kenya's most experienced legal officers, Mr. Justice Connell, supported the removal of the death penalty for rape in 1955 on precisely this basis, whereas another official, writing in the 1940s, claimed that in many cases Africans regarded rape as "little more than a breach of etiquette." 85 That senior judges and colonial officials held such views leads us to better understand the relatively lenient sentences handed down in those cases noted by the CSCCC where convictions were recorded.

The tendency to supress rape allegations characterized the Kenya experience, whether through the use of "preliminary investigations" to delay and deflect cases, the reluctance to tackle unconventional cases (such as those where objects had been inserted into the vaginas of the victims), or the failure to acknowledge the offense of rape when other charges could be referred. All of these tactics have reduced the visibility of rape in the archives from the period, potentially masking the scale of the offense. A similar pattern emerges from the only other colonial counterinsurgency from this period for which archival sources on rape have been examined in any depth: the French campaign in Algeria. In the Algerian War of the 1950s, rape was not a systematic element of French counterinsurgency, Raphaelle Branche argues, but was nonetheless a regular occurrence. ${ }^{86}$ Describing rape as "opportunistic," Branche elaborates the many

83. The best accounts of this remain Anne McClintock, Imperial Leather: Race, Gender and Sexuality in the Imperial Contest (New York: Routledge, 1995); and Ann Stoler, Race and the Education of Desire: Foucault's History of Sexuality and the Colonial Order of Things (Durham, NC: Duke University Press, 1995).

84. Shadle, "Rape in the Courts of Gusiiland," 33.

85. KNA, Jud 4/114, Acting DPP to Registrar, Supreme Court, 2 March 1956; Arthur Phillips, Report on Native Tribunals (Government Printer: Nairobi, 1944), 266. For discussion, see Shadle, "Rape in the Courts of Gusiiland," 33.

86. Branche, "Des Viols Pendant," 123-32. 
contexts in which such "opportunities" were presented, especially in respect of female suspects taken in for questioning, or arrested and held in detention.

The resonance with the Kenyan case is strong. When instances of rape came to the attention of the French authorities, they generally took little interest, treating the rape of an Algerian woman as an immaterial event. Status and race were, therefore, determinant factors in this European response, and this limited the "visibility" of rape in the French archive for Algeria, just as it has in the British archive for Kenya. Branche's findings are drawn from what she admits to be a very fragmentary and limited body of sources, key documents dealing with prosecutions in Algeria, and with specific notorious cases reported at the time, having been withheld by the French authorities ${ }^{87}$ For Algeria, however, as for Kenya, it is clear that although there was no systematic use of rape as a weapon of war, it was a prominent feature of these wars nonetheless. In both conflicts, the reluctance of victims to report cases was undoubtedly affected by their perceived status as rebel supporters, and by their awareness that legal remedies were unlikely to be pursued by the colonial authorities.

\section{Conclusion}

The documentary evidence found in the archival materials of the Hanslope Disclosure provides many echoes of Jane Mara's testimony before the High Court on the sexual torture she suffered at the hands of agents of the British colonial administration in 1954. We cannot know the full extent of rape during the Emergency years in Kenya, but we can now suggest that it was widespread, and that Jane's experience was not uncommon.

Two forms of sexual violence are apparent from the Kenya evidence. First, that experienced by Jane Mara, by the prisoners at the Makadara Home Guard post, and by the detainee at Kirigiti camp, represents a violent torture-related rape perpetrated upon those suspected of being Mau Mau supporters. These assaults might be seen as punishments, or as part of a regime of torture. They only very rarely led to formal complaints or to prosecutions, but they feature prominently in the memoirs and testimonies of women's experience. The second form of sexual violence was the "opportunistic" rape of civilian women by men who were put in authority over them. Through this type of physical and sexual domination, inadequately trained, poorly led, and ill-disciplined police recruits and

87. Ibid., 126-27; and Jean-Clement Martin, "Violences sexuelles, etude des archives, pratiques del'histoire," Annales HSS 3 (1996), 643-61. 
militiamen might assert their violent power over "the enemy." This second type of assault predominates in the cases that came before the CSCCC, with the reporting of cases clustering around those moments when the state was more determined to assert control over its agents. The pattern of cases, and their prosecution and sentencing, thus reflects the actions and political intentions of the state, not of the complainants.

The majority of cases that emerge from the archive accuse Africans of the rape of Kikuyu women. The British colonial authorities tried to prevent such cases from coming to court, especially when the accused were men of the lowest rank and least experience: Loyalist Home Guard militia, or recently recruited police constables. Headmen and other Africans in positions of authority were more likely to be prosecuted, if only for the abuse of their rank that the offense brought. Where the accused were members of the army, the British military insisted on the cases being treated through their own investigations, to avoid civil courts. The approach adopted by the army was then overtly racial: offenses by white troops were dealt with swiftly and relatively harshly (at least by the standards of courtsmartial), whereas those by black troops were not prosecuted at all. For both civilian and military authorities, then, Africans of low rank were not to be held to the same standards as those in positions of higher rank and authority. In the colonial context, this racialized response was reinforced by British anxieties about retaining the loyalty and support of their African forces and allies.

Evidence from other conflicts from the 1940s to the 1970s supports the notion that race and rank were the most salient factors in determining whether rape prosecutions were pursued; however, it seems likely that variations among conflicts turn on political factors. There is no single explanation for how and when rape during wartime will be prosecuted. The historical record suggests that regardless of the frequency, severity, or even verifiability of victims' claims, wartime rape is often only prosecuted when it is politically or militarily expedient to do so. 